\title{
ENVIRONMENTAL SAVING ANALOGY FROM PLASTIC WASTE AT SUPER INDO SUPERMARKET: A HINDU DIDACTIC REVIEW
}

\author{
Author: \\ Fetty Ngatmianingsih \\ Pascasarjana Universitas Hindu Indonesia \\ Denpasar \\ fetty_maryasa@yahoo.co.id
}

\begin{abstract}
The mandatory charge imposed on the customers for single-used plastic bag (KPTG) as an effort to converse the environment from plastic waste, which has been done by Super Indo supermarket, is a positive action towards the company's sustainability strategy. This action goes along with Hindu didactic to have better life such as Canakya Nitisastra XIV, Tri Hita Karana, conserve the environment Sad Kertih, and balance of Bhuana Alit-Agung and Panca Sraddha. Observation and interviews with natural setting (management, store associates and customers) were conducted for this research at five chains of Super Indo.
\end{abstract}

Keywords: analogy, environmental conservation, plastic waste, didactic analysis

\section{INTRODUCTION}

Since the 1940s, plastichad been incorporated to human's life due to its practicality, durability and light-weight. The usage was not only for homeware butalso as the packaging of cosmetics, cleaners, and food. The implication of this consumption is the high amount of plastic waste.

Plastic waste is almost non-degradable as it requires thousand of years to degrade and impose health hazard to all living beings. According to International Fund for Animal Welfare, the dangers of plastic waste are: (1) Unable to be degraded (biodegrade) instead photodegrade and will become micro pollutants; (2) Plastic bag will be degrade within $400-$ 1,000 years; (3) When degrade, the plastic particles will contaminate the soil, water and feed that are directly consumed by animals; (4) In the ocean, the particles will be solidified like a twist because of the whirlpool; (5) On several locations, the amount of these particles are forty six times more than the amount of feedstock in the ocean; (6) Single-used plastic bag caused more than 100,000 deaths of tortoise and other marine animals per year; (7) Single-used plastic bag is one of the twelve debris on the beach; (8) The plastic waste when accumulated becomes POPs (Persistent Organic Pollutants), like PCBs and DDT in high concentration. This pollutant is an endocrine disruptor; (9) Fish and other marine animals will eat the debris thus, accumulating toxic in their digestive system; (10) When the marine animals become the seafood that we consumed then the toxic have been passed down to us.

The danger of plastic waste is serious, looking at the society's consumption behavior which caused the high amount of plastic waste. According to Mintarsih (2016), the modern retail actors generated 9.6 million of single-used plastic waste daily. Those waste, when collected in a year, are equal to 68 A380 Air Bus plane or 353 times the volume of Borobodur temple alias 
9.85 billion of plastic waste. This waste will pollute the environment for 400 years.

It has been an open secret that plastic waste is hazardous but the effort to reduce this waste has yet to take place consistently. One of the efforts is the Kantong Plastik Tidak Gratis (KPTG) program which was on trial from 21 February to 31 May 2016 by the Ministry of Environment and Forestry of the Republic of Indonesia. However, this trial does not have a follow-up.

Many of the modern retailers who had participated in this trial were no longer implement this program. Consumers who shopped at the modern retailers can obtain single-used plastic bag free of charge. The phenomenon of using single-used plastic bag in the society is interesting for research.

Super Indo, a branch of supermarket in Indonesia resulted from the partnership between Salim Group and Ahold Delhaize, has been consistent in implementing KPTG. The reason behind this continuity is the relevancy of KPTG with Super Indo's eight strategies of sustainability in achieving the promises to make a better life. The promises are: a better shopping place (for the consumer), a better neighbor (for people in the surrounding area), and a better work place (for the associates).

It is interesting to investigate the KPTG program at Super Indo from Hindu concept as it can provide the importance to conduct this program, the didactic educative process that is being held, and the factors that influenced its success rate. The aim of this research is to analyze the consciousness level of the society in reducing plastic waste through the usage of reusable shopping bag. Meanwhile, the objective of this research is to analyze the importance in reducing plastic waste to conserve the environment, measuring the effectivity of didactic strategy, and identifying the factors which are influencing the program.

The research was conducted at the headquarter of PT Lion Super Indo, interviews with Corporate Affairs \& Sustainability Managers and at five Super Indo outlets with store managers and cashiers and customers. Structured interviews were conducted in a natural setting. Data analysis used the Miles \& Huberman flow model, and three theoretical foundations, namely phenomenology theory to uncover the phenomenon of society in using plastic bags, rational choice theory to understand people's attitudes in determining the usage of single-used plastic bag, and Vygotsky's theory to determine the effectiveness of the KPTG's understanding process.

\section{DISCUSSION}

\subsection{Sustainability Program at Super Indo}

In order to realize Super Indo's three promises to consumers, employees and the surrounding community for a better life, this company has eight sustainability strategies, namely (1) Super Indo allows customers and employees to eat healthy food every day; (2) Super Indo reduces food waste; (3) Super Indo provides an inclusive workplace; (4) product safety and sustainability; (5) climate impact reducing carbon emissions and waste; (6) employee development; (7) work safety; (8) local community relations.

Some of Super Indo's activities in implementing the sustainability strategy related to the environment are using environmentally friendly freon, inviting the society to do gardening, making liquid fertilizer and compost, partnering with third parties to process used cooking oil (UCO), food donation and reduction of plastic waste. The plastic waste reduction program involves consumers, namely the KPTG.

Initially the plastic waste reduction program to preserve the environment began with Super Indo from 2008, by launching the reusable shopping bag. Super Indo offers this type of bag with the cashier explains the importance of using reuse shopping bags to customers and influences customers to use it. Customers who continue to use plastic bags do not need to pay for single-used plastic bag. In the KPTG program, customers must pay for plastic bags, enforced in 2016 after the KPTG trial ended on May 31, 2016.

Super Indo uses the reuseable shopping bag as a didactic media for customers to reduce plastic waste. At the first design, this bag used rice sack material made from plastic; with go green and Super Indo logo printed on it. The next design had colorful product images printed on it to make the bag interesting - the reason behind it is Super Indo's eagerness to make the customers enthusiastic about using shopping bags. In consideration of the customers' needs 
and to be more environmentally friendly, this material was changed with sponbond and at the same time adjusted the design of the bag to be foldable to make it easy for customers to carry when they are leaving for shopping. This folding design bag is a favorite because besides being easy to carry, the price is less than IDR 10,000 per bag. Beside of this regular shopping bag, Super Indo also offers several bags with more trendy special designs to suit the young mothers.

From 2008 to the 2016 KPTG trial, the environmental conservation program carried out at Super Indo was an appeal to customers to reduce plastic waste through the usage of reusable shopping bag. This appeal was conveyed by officers in the shop, especially the cashier, and through communication media in the store from the parking area to the cashier. Customers can choose to between using the reusable shopping bag, used cardboard or plastic bag for free. The choice aside from being delivered by the cashier there is also apparent in printed media as posters. Education and invitations to use this reusable shopping bag through printed communication and oral communication (cashier) are expected to increase the customers' awareness to use shopping bags from home while shopping. Displaying attractive reuse shopping bags near the cashier area is also expected to be able to educate customers.

The education was perceived as not optimal that in 2013 Super Indo increased its appeal by giving awards in the form of cash back payments to customer who did not use plastic bags at the cashier. A discount of IDR 100 is given if consumers spend a minimum of IDR 50,000 without using the single-used plastic bag with the multiples amount apply. On the other hand, the customers who used the single-used plastic bag from the cashier did not get a payment discount. Customers can use recycled shopping bags and used cardboard if they want cash back.

Since the KPTG trial in February 2016 Super Indo had joined the program by charging customers who use plastic bags for IDR 200 per sheet. The implementation of the KPTG program resulted in a challenge for the cashiers because many customers could not accept and understand the program, even though the government had conducted KPTG socialization. As time goes by, the customers' complaints and questions on this mandatory fee were reduced. The increase in awareness of customers did not received much emphasis from the government because after the trial program ended, alongside its monitoring and evaluation conducted by Mintarsih, the KPTG program did not continue.

Although the KPTG program was not continued, even Aprindo had withdrawn its support on October 1, 2016 (Kompas.com), but Super Indo continues to conduct the program. Customers who use a plastic bag have to pay IDR 200 per sheet as the KPTG program suggested. Meanwhile, there is the cash back program for customers who bring their own reusable shopping bag.

\subsection{The Super Indo Didactic Strategy of the Hindu Concept}

In this KPTG program Super Indo had conducted a didactic education program, where Super Indo conveyed the dangers of plastic waste and urged customers to shop using reuse bags. This educational program takes place in Super Indo outlets and involves customers and cashiers, assisted by existing communication media such as banners, posters, stickers and radio in store. The cashier conveys the material compiled at the Head Office to customers so they can make changes in their shopping attitudes and behavior to use the reuse shopping bag. Educational flow as follows:
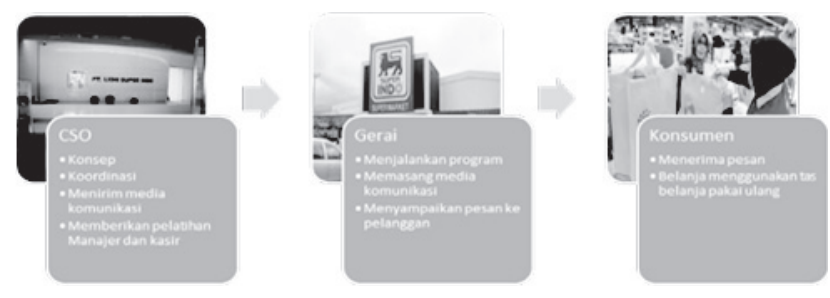

Figure 1. KPTG education flow in Super Indo

Materials compiled by central management are delivered to the store through training of cashiers and store managers. The material was also conveyed in the form of communication media, in the form of plastic waste hazards for the environment and health, plastic waste data and the success of KPTG in other countries. The cashier as the end point of consumer travel in the store is very important in this education role. The cashier has a straightforward communication standard in running the KPTG as shown below: 


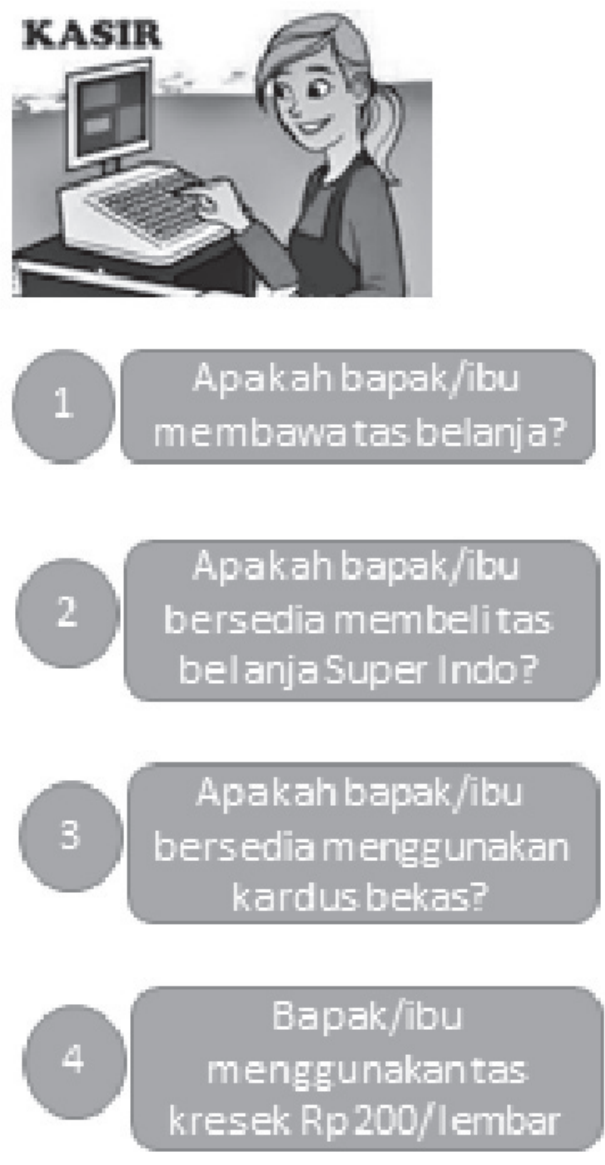

Figure 2. Cashier Communication Standards

In this KPTG communication, the cashier conducts dialogues with the customer thus, questions and answers take place. The communication process provides information on the importance of carrying reusable shopping bags to reduce plastic waste. The cashier must understand this material and be able to communicate well like an educator and must behave like a leader as taught by Ki Hajar Dewantoro ngarso sung tulodo, madya mangun karsa, tut wuri handayani; when customers do not know about the KPTG, the cashier must be able to explain well, when customer already understand they should be able to guide so that customers use a reuse shopping bag (or used boxes), while for the customers who bring their reusable shopping bag, the cashier must give appreciation and enthusiasm to encourage this behavior.

The attitude of the cashier as an agent of change, educator and at the same time the leader in the sales transaction makes the cashier in line with the concept of the Hindu dharmatula, giving good teachings through question and answer. In accordance with the guidelines and training received, the cashier as the door to the end of customer travel while shopping, plays an important role in the success of the KPTG program to invite the customers' participations in the program.

The message in KPTG program is to invite the customers to use reusable shopping bag delivered by the cashier. Change in the customer's behavior is expected to inspire people around them. This program is in line with Canakya Nitisastra XIV.4: jale tailam khale guhyam pātre dānam manāgapi prājne sāstra svayam yāti vistāram vastusaktitah, the translation is 'oil in water, secret to bad people, funds have to the right people, sacred knowledge to wise smart people, slowly all this develops by itself'. It means that everything in the world will live and develop when it is in the right hands. Everything will be good if it is on the right media and will bring a better life.

From the interviews with the customers, it is shown that the role of the cashier is very important in the process of behavior change to adopt reusable shopping bag. The cashier's explanation of the importance of using shopping bags from home and reducing plastic waste can be accepted by the customers. They feel delighted as this process involve a two-way communication.

In addition to the role of the cashier, communication media is very helpful in understanding the program. But the communication media in the store is not big enough thus, less effective compared to mass media such as television. Displaying the reusable shopping bag near the cashier is an attempt by Super Indo to invite consumers to use a re-use shopping bag. Cashiers and communication media and reuse shopping bags are scaffolding in the change process as stated by Vygotsky (Slakind, 2010).

Customers understand about the dangers of plastic waste, but not all of them have the behavior to use reusable shopping bags. The reason behind this is because they need a plastic bag as a waste bag in disposing their household waste. In addition, customers who use their reusable shopping bag still use the single-used plastic bag for the wet or frozen goods to maintain the freshness. This behavior is in line with the research of Michael \& Warren (in 
Audrey et al., 2007) that our actions in solving environmental problems cannot rely on voluntary actions by individual consumers because they do not have complete control over what they consume and how much damage is caused, such as examples awareness of the danger of lead to health caused by lead in gasoline must wait until the oil company produces unleaded gasoline.

The behavior of Super Indo customers in the KPTG program can be explained by voluntary action theory (Parsons in Wirawan, 2012), individual ways of thinking are based on nonlogical and irrational. Subjective decisions always exist and are limited by values, norms, and situations. Individuals as agencies that are part of the structure. Structure and individual relationships are explained through the role of individuals as actors in integration in one system. Interactions between individuals need institutionalization or structures that regulate the pattern of relations between actors. So in this voluntary theory there are elements including (1) actors or individuals; (2) goals; (3) a set of alternatives; (4) influenced by values, norms and ideology; (5) subjective decisions; (6) the role of individuals as actors in integration in one system; (7) the need for institutional structures that regulate the pattern of relations between actors. Cashiers are the main actor in the KPTG's education. Super Indo realizes the importance of their role thus, before the program began, the management provides training to the cashiers, cashier Team Leader, and Store Leader / store manager. Employees' understanding of environmental conservation programs through the reduction of plastic waste was more influenced by the KPTG program in 2016. Super Indo's program in providing reusable shopping bags from 2008 as an environmental conservation effort was poorly understood by employees as they considered these bags as merchandise.

\subsection{The KPTG Education Process Viewed from the Hindu Teachings}

The KPTG as one of the sustainability programs in Super Indo is an effort to reduce plastic waste because plastic waste will cause pollution to the soil, making the land already impure or sacred again, as well as water and air. This effort is in line with the teachings of
Hinduism in maintaining the sanctity of the environment, namely Sad Kertih, which is six attempts to preserve the environment through self-purification (atma kerti), protect and preserve the ocean (samudra kerti), protect forests (wana kerti), conserve springs (danu kerti), preserving the earth and everything that is above it (universe kerti), and trying to maintain social harmony (jana kerti).

Environmental protection efforts at Super Indo aim to be able to maintain existing resources and make a better life. In addition to the KPTG the program carried out by Super Indo in sustainability is working with the surrounding communities in Super Indo activities including gardening and partnership in business. Super Indo makes local farmers as business partners. This is in line with Catur Widya's teachings, which are four aspects that must be balanced in order to create a prosperous society, namely anwiksaski (seeing or watching around / around), weda trayi (three types of Vedas as a source of eternal truth, Regweda / prayer guidelines, Samaweda / worshipping chants guidelines, Yayurweda / guidance in making offerings), warta (ways to strive for prosperity and fertility in terms of agriculture, economic prosperity), and dandaniti (science of government and law).

The program carried out by Super Indo in environmental conservation, not only for the natural environment but also the community environment, makes it better in accordance with three promises, namely better shopping, better neighbors, and a better workplace. This promise to be better to form harmonious or harmonious relationships. Harmony in living in line with the teachings of Tri Hita Karana.

Super Indo maintains good relations between the community and employees. Another relationship to be maintained is between human and the natural environment through environmental conservation, which is one of the efforts that Super Indo has been doing. This is in line with the Hindu teachings to keep the balance between the bhuana alit (micro cosmos, humans) and the bhuana agung (macro cosmos, universe). The relationship between micro-cosmos and macro-cosmos needs to be harmonized because disharmonious relationships will cause negative excesses emerged in bhuana alit emerged through sickness, irritation, unpleasant feelings 
and so on (Ardana et al, 1982).

The education that took place at Super Indo in the KPTG program was to consistently do good. Good deeds will produce good results. Good deeds are to follow existing rules and norms or conditions. This is in line with the teachings of Canakya Nitisastra XIV.1 which mentioned "from the tree of sin itself people get fruit in the form of poverty, disease, grief, bonding and bad habits", meaning that whatever we do if we violate norms, laws and regulations the results are pain, grief, poverty, attachment and bad habits.

If we do things that are not good then we will get bad results (the law of karmaphala, one of the five Hindu beliefs of Panca Sraddha). Bad deeds will cause neraka syuta (hell-born) in punarbhawa (rebirth, one belief in Panca Sraddha). Conversely, if we do good, the results we get are good and will be reborn well. Super Indo has done good things in environmental conservation efforts in order to make a better life in line with the teachings above.

Super Indo philosophy in reducing plastic waste with the KPTG program from three aspects namely environmental, economic and social (Yuvlinda, Corporate Affairs \& Sustainability / CAS manager)

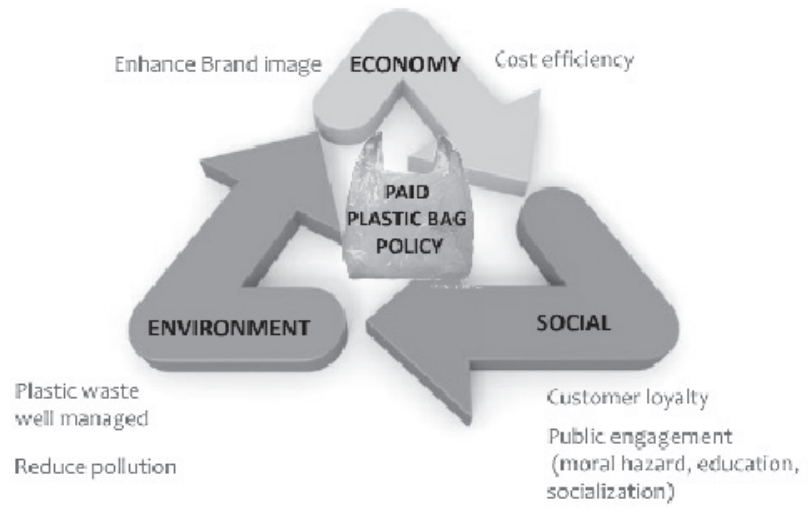

Figure 3. Super Indo's philosophy of the KPTG program

From the environmental aspect Super Indo invites customers to wisely use plastic and manage plastic waste properly. This activity is to reduce pollution due to plastic waste. This is in line with the Hindu teachings of Tri Hita Karana, Sad Kertih, and the balance of bhuana alit-agung .

From an economic aspect, this program will strengthen the image of Super Indo as a retailer who cares about the environment, while simultaneously reducing the cost of using plastic bags. Over the past three years the use of singleused plastic bags has decreased to fifty percent (Yuvlinda, CAS manager). The image of Super Indo is strong because Super Indo consistently conducts the KPTG program and does good things and is spread from consumers to the surrounding community, this is in line with Canakya Nitisastra XIV.1 teachings.

From the social aspect, this program will make Super Indo and community relations closer through education, socialization and involvement in joint activities. Automatically this closeness of society will have an impact on businesses where people become loyal consumers. This is in line with Catur Widya's teachings, namely anwiksaki, looking around and getting ideas and news to make the community more prosperous.

At present Super Indo has run the KPTG program well, where the use of plastic bags has dropped by more than 50 percent in the past three years. The success of this program is influenced by four supporting factors, namely consumer awareness to bring reusable shopping bags from home, cashier services that can explain and invite consumers to use reusable shopping bags, the attraction of reuse shopping bags provided by Super Indo, and the fourth factor is media effective communication provides information on the importance of reducing plastic waste.

Conversely there are factors that hinder this program, namely the need for consumers for plastic bags, product characteristics that require plastic bags to travel from store to house, product packaging, and the fourth is business competition. The phenomenon is that there are some consumers who still use plastic bags even though they have to pay IDR 200 per sheet because they need it for a household garbage disposal. The characteristics of products that need low temperatures to maintain quality such as meat, chicken and fish, cause the use of a separate plastic bag so as not to wet other groceries. Alternative solutions for products like this can use thermal bags, but have not been popular with consumers. Product packaging still uses a lot of plastic material so that consumers have no other choice. Whereas from business competition, consumers can choose other places that can provide plastic bags for free. 
The positive impact of didactic education works well where consumers carry reusable shopping bags while shopping. This business still has the potential to be even better, by developing activities such as providing smaller disposable shopping bags, and making program monitoring and evaluation more structured, and creating a culture of wise use of plastic in every operational step at outlets and headquarters. Employees' understanding of reducing plastic waste is still focused on the KPTG, not reflected in daily operational activities at outlets such as the use of plastic in the process of sorting goods and storing products and packaging.

In addition to Super Indo, the impact of reducing plastic waste with the KPTG will be even greater if the existing retailers implement this program. Thus the culture of shopping with reusable shopping bags will be formed in the wider community. Especially if the traditional traders support and implement the KPTG program consistently. With the implementation of the KPTG in all retailers (modern and traditional), consumers must use the reusable shopping bags whenever they shop to shape the habit of using a reusable shopping bag. Work carried out jointly will get better results, compared to being carried out individually or only part of the community.

The habit shaping requires development in other fields such as infrastructure in handling waste, from household waste, how to dispose of the garbage from the garbage house to the TPS (Tempat Pembuangan Sampah or Waste Disposal Site). For efficiency in handling waste it is necessary to think of a waste disposal system through waste sorting so that the 3R (Reduce, Reuse and Recycle) can run ideally. At present there are several environmental activists who carry out waste management and increase the value of plastic waste, but are still very limited both in terms of area coverage and activities.

The success of environmental conservation by reducing plastic waste will be more successful if all levels of society actively participate. Planning preparation is needed in waste management, and the availability of facilities and infrastructure. Support from environmental activists and the government will accelerate the shaping of this habit.

\section{CONCLUSION}

The KPTG program at Super Indo is in line with eight sustainability strategies and is an effort to fulfill three company promises for a better life. This effort is in line with the didactic teachings of Hinduism to do good in realizing a better life in accordance with the life goals of Hindus mokshartam jagadita ya ca iti dharma. The program philosophy of the three specs (environmental, social, and economic) is in line with the teachings of the Hindu Tri Hita Karana, Sad Kertih, the balance of Bhuana Alit-Agung, Catur Widya (anwiksaski, warta), and Canakya Nitisastra XIV.1 and 4. Teaching process didaktis at Super Indo needs to be developed and disseminated so that environmental preservation by reducing plastic waste can be realized better and faster. 


\section{REFERENCES}

Ardana, I Gusti Gde, Ida Bagus Putu Parwita, Ni Made Sri Arwati.1982. Agama Hindu dan Lingkungan Hidup. Proyek Seminar Kesatuan Tafsir Terhadap Aspek-Aspek Agama Hindu Tahun 1981/1982. Denpasar.

Darmayasa. 1992. Canakya Nitisastra. Hanuman Sakti Jakarta.

Mintarsih, T.Hendrawati. 2016. Kebijakan Kantong Plastik Tidak Gratis. Monitoring dan Evaluasi. Jakarta: Direktorat Jenderal Pengelolaan Sampah. Limbah, dam Bahan Beracun Berbahaya, 27 Juli 2016.

Salkind, N.J. 2010. Teori-Teori Perkembangan Manusia. Pengantar Menuju Pemahaman Holistik. Cetakan II. Bandung: Penerbit Nusa Media.

Wirawan, I.B. 2013. Teori-Teori Sosial dalam Tiga Paradigma. Fakta Sosial, Definisi Sosial \& Perilaku Sosial. Jakarta: Kencana Prenadamedia Group.

--------. Plastic Bag Environmental Impact. Available from, URL: http://conservingnow.com/ plastic-bag-environmnet-impact 